MSC 47J05

DOI: $10.14529 / \mathrm{mmp} 140409$

\title{
ON THE UNIQUENESS OF A NONLOCAL SOLUTION IN THE BARENBLATT - GILMAN MODEL
}

\author{
E.A. Bogatyreva, South Ural State University, Chelyabinsk, Russian Federation, \\ bogatyrevaea@susu.ac.ru,
} I.N. Semenova, Ural State Pedagogical University, Yekaterinburg, Russian Federation, semenova_i_n@mail.ru

This article deals with the question of uniqueness of a generalized solution to the Dirichlet-Cauchy problem for the Barenblatt-Gilman equation, which describes nonequilibrium countercurrent capillary impregnation. The unknown function corresponds to effective saturation. The main equation of this model is nonlinear and implicit with respect to the time derivative, which makes it quite hard to study. In a suitable functional space, the Dirichlet-Cauchy problem for the Barenblatt-Gilman equation reduces to the Cauchy problem for a quasilinear Sobolev-type equation. Sobolev-type equations constitute a large area of nonclassical equations of mathematical physics. The techniques used in this article originated in the theory of semilinear Sobolev-type equations. For the Cauchy problem we obtain a sufficient condition for the existence of a unique generalized solution. We establish the existence of a unique nonlocal generalized solution to the Dirichlet-Cauchy problem for the Barenblatt-Gilman equation.

Keywords: Barenblatt-Gilman equation; quasilinear Sobolev-type equation; generalized solution.

\section{Introduction}

The Barenblatt-Gilman mathematical model [1] amounts to the equation

$$
u_{t}-\lambda \alpha(\Delta \Phi(u))_{t}=\alpha \Delta \Phi(u)
$$

with the Dirichlet-Cauchy conditions

$$
\begin{gathered}
u(x, t)=0,(x, t) \in \partial \Omega \times(0, \tau), \\
u(x, 0)=u_{0}(x), x \in \Omega,
\end{gathered}
$$

where $\Omega \subset \mathbb{R}^{n}$ is a bounded region with boundary of class $C^{\infty}$, the function $\Phi(u) \equiv|u|^{p-2} u$ with $p \geq 2$ is monotonely increasing and smooth, while $\tau, \alpha$, and $\lambda$ are positive real parameters.

This equation models nonequilibrium countercurrent capillary impregnation. In a suitable functional space we reduce $(0.1)-(0.3)$ to the Cauchy problem

$$
u(0)=u_{0}
$$


for the abstract operator differential equation

$$
\frac{d}{d t}(L(u))+M(u)=0
$$

where $L(u)=A u+\lambda M(u)$ with $\lambda \in \mathbb{R}_{+}$. This is a quasilinear Sobolev-type equation. Implicit equations attract many researchers [2-5]. This article continues [7], which dealt with the question of the existence of a generalized solution to $(0.1)-(0.3)$.

\section{Abstract Cauchy Problem}

Consider a real Hilbert space $\mathfrak{H}=(\mathfrak{H},\langle\cdot, \cdot\rangle)$ identified with its dual and equipped with a dual pair of reflexive Banach spaces $\mathfrak{U} \equiv(\mathfrak{U},\|\cdot\|)$ and $\mathfrak{U}^{*} \equiv\left(\mathfrak{U},\|\cdot\|_{*}\right)$ such that we have a continuous dense embedding $\mathfrak{U} \hookrightarrow \mathfrak{H} \hookrightarrow \mathfrak{U}^{*}$. Take an operator $M \in C^{r+1}\left(\mathfrak{U} ; \mathfrak{U}^{*}\right)$ with $r \in \mathbb{N}$ and an operator $A \in \mathfrak{L}\left(\mathfrak{U} ; \mathfrak{U}^{*}\right)$.

Definition 1. A vector function $u \in L_{\infty}(0, \tau ; \mathfrak{U})$ such that $\frac{d u}{d t} \in L_{2}(0, \tau ; \mathfrak{H})$ for $\tau \in \mathbb{R}_{+}$ is called a generalized solution to problem (0.4), (0.5) whenever it satisfies

$$
\left\langle\frac{d}{d t} L(u(t)), v\right\rangle+\langle M(u(t)), v\rangle=0 \text { for almost all } t \in(0, \tau)
$$

and

$$
\left\langle u(0)-u_{0}, v\right\rangle=0 \text { for all } v \in \mathfrak{U}
$$

Theorem 1. [6] Take two operators $A \in \mathfrak{L}\left(\mathfrak{U} ; \mathfrak{U}^{*}\right)$ and $M \in C^{r+1}\left(\mathfrak{U} ; \mathfrak{U}^{*}\right)$ with $r \in \mathbb{N}$ and suppose that at $u_{0} \in \mathfrak{U}$ the operator $N\left(u_{0}\right): \mathfrak{U} \rightarrow \mathfrak{U}^{*}$ is a toplinear isomorphism. Then there exists a unique local solution to problem (0.4), (0.5) passing through the point $u_{0}$.

Theorem 2. [7] Take an operator $M \in C^{r+1}\left(\mathfrak{U} ; \mathfrak{U}^{*}\right)$ with $r \in \mathbb{N}$ which is s-monotone, $p$-coercive, and homogeneous of degree $k \in \overline{\mathbb{R}}_{+}$, and, furthermore, its Fréchet derivative is symmetric, and a positive definite symmetric operator $A \in \mathfrak{L}\left(\mathfrak{U} ; \mathfrak{U}^{*}\right)$. If problem $(0.4),(0.5)$ has a unique local solution on some interval $\left(-\tau_{0}, \tau_{0}\right)$ with $\tau_{0} \in \mathbb{R}_{+}$then it has a generalized solution.

Condition 1. If there exists a function $F \in C[0, \infty)$, possibly after a change on a negligible set, such that $F(s) \geq 0$ for almost all $s \in[0, \infty)$ and

$$
\|M(u)-M(v)\|_{*} \leq F\left(s_{0}\right)\|u-v\|
$$

for almost all $s_{0} \in[0, \infty)$ and all $u=u\left(s_{0}\right), v=v\left(s_{0}\right) \in \mathfrak{U}$ then we say that the operator $M: \mathfrak{U} \rightarrow \mathfrak{U}^{*}$ satisfies condition 1 .

Definition 1 of a generalized nonlocal solution to problem $(0.4),(0.5)$ is equivalent [8] to

Definition 2. Refer as a weak generalized solution to the Cauchy problem (0.4), (0.5) to a function $u(t) \in L_{\infty}(0, \tau, \mathfrak{U})$ with $\frac{d u}{d t} \in L_{2}(0, \tau, \mathfrak{U})$ satisfying

$$
\begin{gathered}
\int_{0}^{\tau}\left(\frac{d}{d t}\langle L(u), w\rangle+\langle M(u), w\rangle\right) \varphi(t) d t=0 \\
u(0)=u_{0}, \forall w \in \mathfrak{U}, \forall \varphi \in L_{2}(0, \tau) .
\end{gathered}
$$


Theorem 3. Suppose that for $u_{0} \in \mathfrak{U}$ a generalized solution to problem (0.4), (0.5) exists. If the operator $M \in C^{r+1}\left(\mathfrak{U} ; \mathfrak{U}^{*}\right)$, with $r \in \mathbb{N}$, is s-monotone and satisfies condition 1 , while the operator $A \in \mathfrak{L}\left(\mathfrak{U} ; \mathfrak{U}^{*}\right)$ is positive definite, then this solution is unique.

Proof. Consider two distinct weak generalized solutions $u_{1}$ and $u_{2}$ to problem $(0.4),(0.5)$ in the sense of Definition 2.

Take $\varphi(t) \equiv 1 \in L_{2}(0, \tau)$. Then for almost all $t \in(0, \tau)$ we infer from (1.1) that

$$
\int_{0}^{t}\left(\frac{d}{d s}\left\langle L\left(u_{i}\right), w\right\rangle+\left\langle M\left(u_{i}\right), w\right\rangle\right) d s=0, \forall w \in \mathfrak{U}, i=1,2
$$

where $L(u)=A u+\lambda M(u)$. Integrating (1.2) yields

$$
\left\langle A u_{i}(t)+\lambda M\left(u_{i}(t)\right), w\right\rangle+\int_{0}^{t}\left\langle M\left(u_{i}(s)\right), w\right\rangle d s=\left\langle A u_{0}+\lambda M\left(u_{0}\right), w\right\rangle, \forall w \in \mathfrak{U}, i=1,2 .
$$

Subtract from (1.3) for $u_{1}$ the same equation for $u_{2}$ and put $v=u_{1}-u_{2}$. Then

$$
\langle A v, w\rangle+\lambda\left\langle M\left(u_{1}(t)\right)-M\left(u_{2}(t)\right), w\right\rangle+\int_{0}^{t}\left\langle M\left(u_{1}(s)\right)-M\left(u_{2}(s)\right), w\right\rangle d s=0, \forall w \in \mathfrak{U}
$$

Since $u_{i} \in L_{\infty}(0, \tau, \mathfrak{U})$, it follows that $v(\alpha) \in \mathfrak{U}$ for almost all $\alpha \in(0, \tau)$. Therefore, (1.4) yields

$$
\langle A v, v\rangle+\lambda\left\langle M\left(u_{1}(\alpha)\right)-M\left(u_{2}(\alpha)\right), v\right\rangle=\int_{0}^{\alpha}\left\langle M\left(u_{2}(s)\right)-M\left(u_{1}(s)\right), v(\alpha)\right\rangle d s .
$$

Since $A$ is a positive definite operator for all $u \in \mathfrak{U}$, we have

$$
\langle A u, u\rangle \geq m\|u\|_{\mathfrak{H}}^{2}, m>0 .
$$

In addition, since $M$ is an $s$-monotone operator, it follows that

$$
\left\langle M\left(u_{1}(\alpha)\right)-M\left(u_{2}(\alpha)\right), v\right\rangle \geq 0 .
$$

By (1.5)-(1.7) we arrive at

$$
\|v(\alpha)\|^{2} \leq m^{-1} \int_{0}^{\alpha}\left\langle M\left(u_{2}(s)\right)-M\left(u_{1}(s)\right), v(\alpha)\right\rangle d s .
$$

Now Hölder's inequality implies that

$$
\|v(\alpha)\|^{2} \leq m^{-1}\|v(\alpha)\| \int_{0}^{\alpha}\left\|M\left(u_{2}(s)\right)-M\left(u_{1}(s)\right)\right\| d s .
$$


Since $M$ satisfies condition 1 , we infer that

$$
\|v(\alpha)\|^{2} \leq\|v(\alpha)\| \int_{0}^{\alpha} F(s)\|v(s)\| d s
$$

and then the Gronwall-Bellman lemma [9] shows that $u_{1}=u_{2}$ almost everywhere.

\section{The Dirichlet-Cauchy Problem for the Barenblatt-Gilman Equation}

Let us reduce problem $(0.1)-(0.3)$ to the abstract problem $(0.4),(0.5)$. Take $\mathfrak{H}=W_{2}^{-1}(\Omega)$ with the inner product

$$
\langle u, v\rangle=\int_{\Omega} u(-\Delta)^{-1} v d x, u, v \in \mathfrak{H},
$$

where $(-\Delta)^{-1}$ is the Green operator of the homogeneous Dirichlet problem for the Poisson equation $\Delta u=f$ in $\Omega$. Choose the space $L_{p}(\Omega)$ as $\mathfrak{U}$ since $L_{p}(\Omega) \hookrightarrow L_{2}(\Omega)$ for $p \in[2,+\infty)$ in the case of a bounded region $\Omega$, which we have, while $L_{2}(\Omega) \hookrightarrow W_{2}^{-1}(\Omega)$. Then we can take as $\mathfrak{U}^{*}$ the dual space to $\mathfrak{U}$ with respect to the duality (2.1). In this case the embedding $\mathfrak{U} \hookrightarrow \mathfrak{H} \hookrightarrow \mathfrak{U}^{*}$ for $p \in[2,+\infty)$ is dense and continuous. Define the operator $A$ as

$$
\langle A u, v\rangle=\langle u, v\rangle=\int_{\Omega} u(-\Delta)^{-1} v d x, u, v \in \mathfrak{U}
$$

and the operator $M$ as

$$
\langle M(u), v\rangle=\alpha \int_{\Omega}|u|^{p-2} u v d x, \quad u, v \in \mathfrak{U} .
$$

Lemma 1. The operator $M$ satisfies condition 1.

Proof. There exists a nonnegative continuous function $g: \mathbb{R}^{2} \rightarrow \mathbb{R}$ such that

$$
\left.|| u\right|^{p-2} u-|v|^{p-2} v|\leq g(u, v)| u-v \mid
$$

for all $u, v \in \mathbb{R}$. It is easy to show that, for instance, the function

$$
g(u, v)= \begin{cases}\frac{\|\left. u\right|^{p-2} u-|v|^{p-2} v \mid}{|u-v|} & \text { for } u \neq v \\ (p-2)|u|^{p-1} & \text { for } u=v\end{cases}
$$

satisfies these conditions. By (2.2), for all real-valued functions $u=u(x, s)$, $v=v(x, s) \in \mathfrak{U}$

$$
\left.|| u\right|^{p-2} u-|v|^{p-2} v|\leq f(x, s)| u-v \mid
$$

almost everywhere, where $f(x, s)=g(u(x, s), v(x, s))$. It follows from (2.3) that

$$
\sup _{\|w\|=1} \alpha \int_{\Omega}\left\|\left.u\right|^{p-2} u-|v|^{p-2} v\right\| w\left|d x \leq \sup _{\|w\|=1} \alpha \int_{\Omega} f(x, s)\right| u-v \| w \mid d x .
$$


In the left-hand side we have

$$
\begin{gathered}
\sup _{\|w\|=1} \alpha \int_{\Omega}\left\|\left.u\right|^{p-2} u-|v|^{p-2} v\right\| w\left|d x \geq \sup _{\|w\|=1} \alpha\right| \int_{\Omega}|u|^{p-2} u w d x-\int_{\Omega}|v|^{p-2} v w d x \mid= \\
=\sup _{\|w\|=1}|\langle M(u)-M(v), w\rangle|=\|M(u)-M(v)\|_{*} .
\end{gathered}
$$

In the right-hand side we have

$$
\begin{gathered}
\sup _{\|w\|=1} \alpha \int_{\Omega} f(x, s)\left|u-v\left\|w \left|d x=\sup _{\|w\|=1} \alpha\langle f(x, s)|u-v|,|w|\rangle \leq \sup _{\|w\|=1} \alpha\|f(x, s)|u-v|\|_{L_{2}}\|w\|_{L_{2}} \leq\right.\right.\right. \\
\leq \alpha a\|f(x, s)|u-v|\|_{L_{2}} \leq \alpha C\|f(x, s)\|\|u-v\|=F(s)\|u-v\| .
\end{gathered}
$$

Hence,

$$
\|M(u)-M(v)\|_{*} \leq F(s)\|u-v\|
$$

In the case $p \geq 2$ the existence of a generalized solution to problem $(0.1)-(0.3)$ for arbitrary initial conditions is established in [7]. Thus, Lemma 1 implies

Theorem 4. Assume that $p \geq 2$ and take $\alpha, \lambda \in \mathbb{R}_{+}$. Then for every $u_{0} \in \mathfrak{U}$ and every $\tau \in \mathbb{R}_{+}$there exists a unique generalized solution to problem $(0.1)-(0.3)$.

\section{References}

1. Barenblatt G.I., Gilman A.A. [Mathematical Model of the Countercurrent Capillary Impregnation]. Inzhenerno-fizicheskiy zhurnal [Journal of Engineering Physics and Thermophysics], 1987, vol. 52, no. 3, pp. 456-461. (in Russian)

2. Zagrebina S.A., Sagadeeva M.A. [The Generalized Showalter-Sidorov Problem for the Sobolev Type Equations with strongly $(L, p)$-radial operator] Vestnik MaGU. Matematika [Bulletin of the Magnitogorsk State University], 2006, no 9, pp. 17-27. (in Russian)

3. Keller A.V. [The Leontief Type Systems: Classes of Problems with the ShowalterSidorov Intial Condition and Numerical Solving] Izvestiya Irkutskogo gosudarstvennogo universitita. Seriya: Matematika [The Bulletin of Irkutsk State University. Series: Mathematics], 2010, no 2, pp. 30-43. (in Russian)

4. Sviridyuk G.A., Zagrebina S.A. Verigin's Problem for Linear Equations of the Sobolev Type with Relatively P-Sectorial Operators. Differential Equations, 2002, vol. 38, no. 12, pp. 1745-1752. DOI: 10.1023/A:1023812213901

5. Sviridyuk G.A., Zamyshlyaeva A.A. The Phase Spaces of a Class of Linear Higher-Order Sobolev Type Equations. Differential Equations, 2006, vol. 42, no. 2, pp. 269-278. DOI: 10.1134/S0012266106020145

6. Manakova N. A., Bogatyreva E.A. [Numerical Research of Processes in the Barenblatt - Gilman Model]. Vestnik MaGU. Matematika [Bulletin of the Magnitogorsk State University], 2013, issue 15, pp. 58-67. (in Russian) 
7. Manakova N. A., Bogatyreva E.A. [On a Solution of the Dirichlet - Cauchy Problem for the Barenblatt - Gilman Equation]. Izvestiya Irkutskogo gosudarstvennogo universitita. Seriya: Matematika [The Bulletin of Irkutsk State University. Series: Mathematics], 2014, vol. 7, pp. 52-60. (in Russian)

8. Al'shin A.B., Korpusov M.O., Sveshnikov A.G. Blow-up in Nonlinear SobolevType Equations. Berlin, N.-Y., Walter de Gruyter GmbH \& Co. KG, 2011. DOI: $10.1515 / 9783110255294$

9. Demidovich B.P. Lektsii po matematicheskoy teorii ustoychivosti [Lectures on the mathematical theory of stability]. Moscow, Nauka, 1967. (in Russian)

Received May 16, 2014

УДК 517.9

DOI: $10.14529 / \mathrm{mmp} 140409$

\section{О ЕДИНСТВЕННОСТИ НЕЛОКАЛЬНОГО РЕШЕНИЯ МОДЕЛИ БАРЕНБЛАТТА - ГИЛЬМАНА}

\section{Е.А. Богатырева, И.Н. Семенова}

В работе рассматривается вопрос единственности обобщенного решения задачи Дирихле - Коши для уравнения Баренблатта - Гильмана. Это уравнение описывает неравновесную противоточную капиллярную пропитку. Неизвестная функция соответствует функции эффективной насыщенности. Основное уравнение модели является нелинейным и не разрешимо относительно производной по времени, что создает значительные трудности при его рассмотрении. Задача Дирихле - Коши для уравнения Баренблатта - Гильмана в подходящих функциональных пространствах редуцируется к задаче Коши для квазилинейного уравнения соболевского типа. Уравнения соболевского типа составляют обширную область неклассических уравнений математической физики. Методы исследования, которые используются в работе, первоначально возникли в теории полулинейных уравнений соболевского типа. Для задачи Коши получено достаточное условие существования единственного обобщенного решения. Показано существование единственного нелокального обобщенного решения задачи Дирихле Коши для уравнения Баренблатта - Гильмана.

Ключевые слова: уравнение Баренблатта-Гильмана; квазилинейное уравнение соболевского типа; обобщенное решение.

\section{Литература}

1. Баренблатт, Г.И. Математическая модель неравновесной противоточной капиллярной пропитки / Г.И. Баренблатт, А.А. Гильман // Инженерно-физический журнал. - 1987. - Т. 52, № 3. - С. 456-461.

2. Загребина, С.А. Обобщенная задача Шоуолтера - Сидорова для уравнений соболевского типа с сильно $(L, p)$-радиальным оператором / C.А. Загребина, M.A. Caгадеева // Вестник Магнитогорского государственного университета. - 2006. № 9. - C. 17-27. 
3. Келлер, А.В. Системы леонтьевского типа: классы задач с начальным условием Шоуолтера-Сидорова и численные решения / А.В. Келлер // Известия Иркутского государственного университета. Серия: Математика. - 2010. - № 2. - С. 30-43.

4. Свиридюк, Г.А. Задача Веригина для линейных уравнений соболевского типа с относительно $p$-секториальными операторами / Г.А. Свиридюк, С.А. Загребина // Дифференциальные уравнения. - 2002. - Т. 38, № 12. - С. 1646.

5. Свиридюк, Г.А. Фазовые пространства одного класса линейных уравнений соболевского типа высокого порядка / Г.А. Свиридюк, А.А. Замышляева // Дифференциальные уравнения. - 2006. - Т. 42, № 2. - С. 252-260.

6. Манакова, Н.А. Численное исследование процессов в модели БаренблаттаГильмана / Н.А. Манакова, Е.А. Богатырева // Вестник МаГУ. Математика. - 2013. - Вып. 15. - С. 58-67.

7. Манакова, Н.А. О решении задачи Дирихле-Коши для уравнения БаренблаттаГильмана / Н.А. Манакова, Е.А. Богатырева // Известия Иркутского государственного университета. Серия: Математика. - 2014. - Т. 7. - С. 52-60.

8. Al'shin, A.B. Blow-up in Nonlinear Sobolev-Type Equations / A.B. Al'shin, M.O. Korpusov, A.G. Sveshnikov. - Berlin, N.-Y.: Walter de Gruyter GmbH \& Co. KG, 2011.

9. Демидович, Б.П. Лекции по математической теории устойчивости / Б.П. Демидович. - М: Наука, 1967.

Статья подготовлена в рамках выполнения работ по госзаданию МОиН РФ 20014-392, проект 1942.

Екатерина Александровна Богатырева, ассистент, кафедра «Уравнения математической физики», Южно-Уральский государственный университет (г. Челябинск, Российская Федерация), bogatyrevaea@susu.ac.ru.

Ирина Николаевна Семенова, кандидат педагогических наук, кафедра «Теория и методика обучения математике», Уральский государственный педагогический университет (г. Екатеринбург, Российская Федерация), semenova_i_n@mail.ru.

Поступила в редакиию 16 мая 2014 г. 